University of Nebraska - Lincoln

DigitalCommons@University of Nebraska - Lincoln

USDA Wildlife Services - Staff Publications

U.S. Department of Agriculture: Animal and Plant Health Inspection Service

2015

\title{
AN INDIVIDUAL-BASED MODEL FOR FERAL HOGS IN GREAT SMOKY MOUNTAINS NATIONAL PARK
}

\author{
Rene A. Salinas \\ Appalachian State University, salinasra@appstate.edu \\ William H. Stiver \\ National Park Service \\ Joseph L. Corn \\ University of Georgia \\ Suzanne Lenhart \\ University of Tennessee \\ Charles Collins \\ University of Tennessee
}

See next page for additional authors

Follow this and additional works at: https://digitalcommons.unl.edu/icwdm_usdanwrc

Part of the Life Sciences Commons

Salinas, Rene A.; Stiver, William H.; Corn, Joseph L.; Lenhart, Suzanne; Collins, Charles; Madden, Marguerite; VerCauteren, Kurt C.; Schmit, Brandon S.; Kasari, Ellen; Odoi, Agricola; Hickling, Graham; and McCallum, Hamish, "AN INDIVIDUAL-BASED MODEL FOR FERAL HOGS IN GREAT SMOKY MOUNTAINS NATIONAL PARK" (2015). USDA Wildlife Services - Staff Publications. 1663.

https://digitalcommons.unl.edu/icwdm_usdanwrc/1663

This Article is brought to you for free and open access by the U.S. Department of Agriculture: Animal and Plant Health Inspection Service at DigitalCommons@University of Nebraska - Lincoln. It has been accepted for inclusion in USDA Wildlife Services - Staff Publications by an authorized administrator of DigitalCommons@University of Nebraska - Lincoln. 


\section{Authors}

Rene A. Salinas, William H. Stiver, Joseph L. Corn, Suzanne Lenhart, Charles Collins, Marguerite Madden, Kurt C. VerCauteren, Brandon S. Schmit, Ellen Kasari, Agricola Odoi, Graham Hickling, and Hamish McCallum 


\title{
AN INDIVIDUAL-BASED MODEL FOR FERAL HOGS IN GREAT SMOKY MOUNTAINS NATIONAL PARK
}

\author{
RENÉ A. SALINAS* \\ Department of Mathematical Sciences, Appalachian State University, Boone, NC 28608
}

WILLIAM H. STIVER

United States Department of Interior, National Park Service, Gatlinburg, TN 37738

JOSEPH L. CORN

Southeastern Cooperative Wildlife Disease Study, College of Veterinary Medicine, The University of Georgia, Athens, GA 30602

SUZANNE LENHART and CHARLES COLLINS

Department of Mathematics, University of Tennessee, Knoxville, TN 37996

\section{MARGUERITE MADDEN}

Department of Geography, Center for Remote Sensing and Mapping Science, University of

Georgia, Athens, GA 30602

KURT C. VERCAUTEREN

United States Department of Agriculture, APHIS/Wildlife Services, National Wildlife Research Center, Fort Collins, CO 80521

BRANDON B. SCHMIT

United States Department of Agriculture, APHIS/Wildlife Services, National Wildlife Disease Program, Fort Collins, CO 80521

ELLEN KASARI

United States Department of Agriculture, APHIS/Veterinary Services, Fort Collins, CO 80521

AGRICOLA ODOI

Department of Clinical Sciences, The University of Tennessee, Knoxville, TN 37996

GRAHAM HICKLING

Department of Forestry, Center for Wildlife Health, Wildlife, and Fisheries, University of Tennessee, Knoxville, TN 37996

\section{HAMISH MCCALLUM}

School of Environment, Griffith University, Nathan, Qld 4111, Australia

\begin{abstract}
The expansion of feral hog (Sus scrofa) populations in the United States has resulted in increased efforts to develop and implement control strategies designed to minimize the impacts done by this invasive species. We describe an individual-based model for feral hogs in Great Smoky Mountains National Park (GSMNP). The objectives of the model are to provide an understanding of the population dynamics of this feral hog population and to determine the efficacy of the annual harvest as a population control method. Results suggest that the dynamics of the population are driven by
\end{abstract}

\footnotetext{
${ }^{*}$ Corresponding author. René A. Salinas, Department of Mathematical Sciences, Appalachian State University, Boone, NC, USA, e-mail: salinasra@appstate.edu

Received by the editors on $7^{\text {th }}$ July 2014. Accepted $30^{\text {th }}$ December 2014. 
fall hard mast production and the GSMNP harvests currently limit growth of the population, but these control efforts have not reduced the population.

KEY Words: Sus scrofa, Eurasian wild boar, invasive species, individual-based model, feral hog, hard mast.

1. Introduction. The World Conservation Union (IUCN) lists the feral pig as one of the world's 100 worst alien invasive species (Lowe et al. [2000]). Their high reproductive potential and omnivorous feeding habits, along with intra- and interstate transport and illegal release have made control of this species in the U.S. difficult. Hunting is a common control strategy that removes an average of $23 \%$ of the population annually, but varies significantly across regions (8-50\%) (Mayer [2009]). Harvest rates are often hard to measure because of limited feedback from hunters.

Great Smoky Mountains National Park (GSMNP) hogs are a hybrid population of the European wild boar, introduced in the early 1900s, and feral hogs ((wildliving hogs that are solely of domestic ancestry)). We use the term feral hog in this paper to refer this hybrid population. Feral hogs initially expanded their range into GSMNP during the late 1940s and early 1950s (Stiver and Delozier [2009]). Impacts in the park include depredation of native fauna, consumption of native plants, competition with native fauna for resources, and introduction of disease. The GSMNP has been attempting to control the feral hog population via harvesting (i.e., control shooting and trapping) since the 1959 (Stiver and Delozier [2009]). However, limited empirical data on the population has made it difficult for managers to determine the effectiveness of these harvest efforts.

Movement and reproductive dynamics of feral hogs are driven by seasonal variation in resource availability, the principle component being annual variation in fall hard mast (acorns and other nuts) (Singer et al. [1981]). During fall mast failures, movement distances increase (searching for food) and reproductive success decreases (not enough food reserves). Hogs can compensate for a resource induced litter failure by having a second litter within the year. Also, because feral hogs reach reproductive maturity as early as 6 months, the population is able to rebound quickly during good mast years.

Individual-based models (IBMs) help provide insight into the management of wildlife populations and are becoming increasingly popular (McClane et al. [2011]). IBMs can include a level of spatial, temporal, and demographic resolution that allow managers to use much of the empirical data available and test applicable management scenarios. For the GSMNP region, much of the empirical life history data for feral hogs is at the individual level, and the existing population level data are limited to spatial distribution and harvest numbers. Given these facts, an IBM is an appropriate choice for this population. In this paper, we describe the IBM and present empirical comparisons. After evaluating various results from the model, we present results that provide insight into the impact of the GSMNP control efforts on the local feral hog population. 


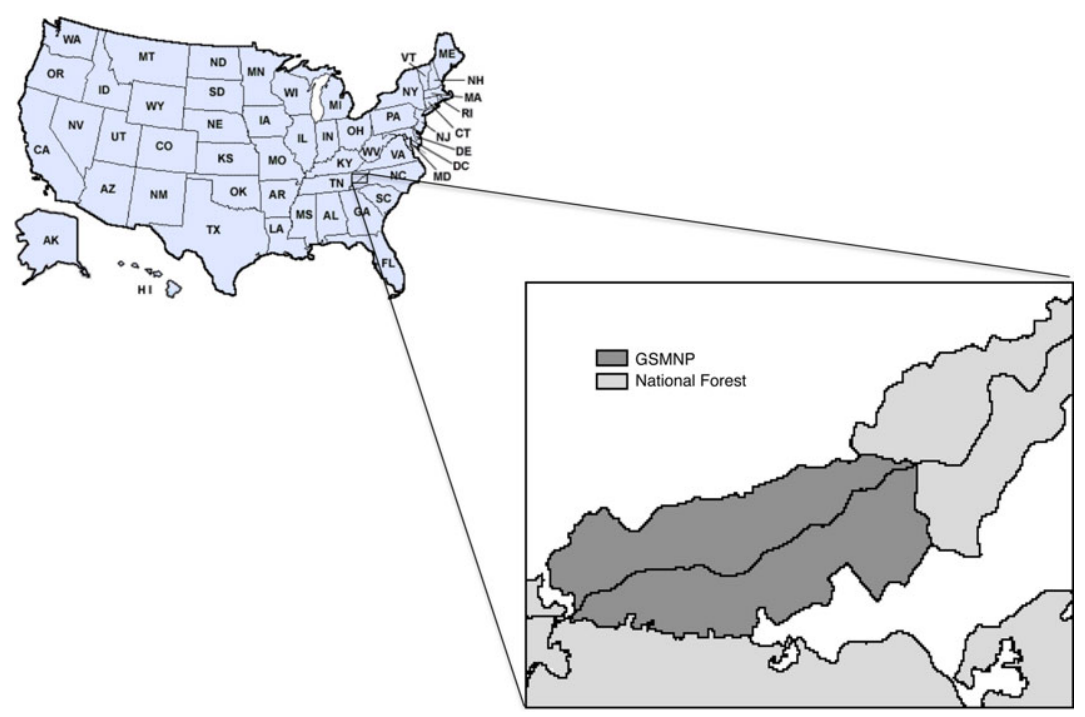

FIGURE 1. The study region for this project includes parts of east Tennessee and western North Carolina that surround Great Smoky Mountains National Park.

2. Model description. This section follows the Overview, Design concepts, and Details (ODD) protocol for describing IBMs (Grimm et al. [2006, 2010]).

2.1. Purpose. The main purpose of the model is to provide managers with a tool for the assessment of management strategies on the dynamics of the feral hog population in GSMNP.

2.2. Entities, state variables, and scales. The model includes two kinds of state variables: hogs and grid cells. Hogs are characterized by their age (in days), ID number, location (grid cell), gender, disease state, and food intake. Females include the following additional variables: reproductive status (normal, in estrus, gestating, or weaning) and number of piglets. The model world is two-dimensional with each cell representing $450 \mathrm{~m} \times 450 \mathrm{~m}$ on a $270 \times 200$ cell landscape (Figure 1 ). Grid cells are designated with integer valued raster layers that include forest type and GSMNP/national forest boundaries. Grid cells also characterized food availability, which is a function of forest type and month.

2.3. Process overview and scheduling. The following processes run on a daily time step in the order shown in Figure 2. Reproduction is not on the daily list because those functions are dependent on an individual's state and not time. Reproduction is described in detail in Section 2.2.7.

Mast Update: Twice a month, a lookup table and a set of functions are used to determine the amount of food available for individuals on the landscape. 


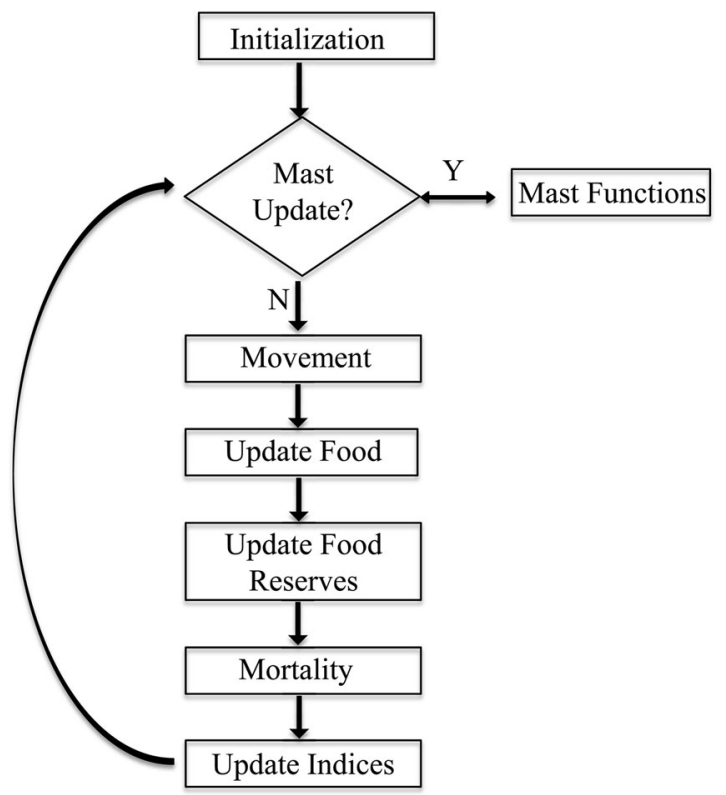

FIGURE 2. Flow diagram for the model. Note that reproduction events take place in different compartments.

Movement: Movement is differentiated by gender and is driven by food availability. The presence of other hogs also affects movement.

Update Food: Once individuals have moved to a new cell, each individual removes a predetermined amount of food (varies monthly) from that cell.

Update Food Reserves: The amount of food removed from the grid cell by an individual is converted to a stored reserve state variable. This is particular importance for gestating females.

Mortality: All independent individuals (adults and solitary juveniles) are subject to two types of mortality: natural and harvest. Events are determined by random assortment of individuals and a uniform probability. If a weaning sow dies, her litter dies. If, during weaning, a females food reserves fall below a threshold level, her litter dies.

Update Indices: Each state variable with a timed index, like age, is updated. If a variable reaches it's corresponding threshold value any changes are implemented (e.g., if the threshold for gestation time is reached, the individual gives birth).

\subsection{Design concepts.}

2.4.1. Emergence. Population-level dynamics emerge from a set of imposed rules and parameters that can be affected by an individual's response to food availability 
and the presence of other hogs. These include population-level reproduction and demographic patterns.

2.4.2. Sensing. Individual hogs can sense the amount of food available and the presence of hogs in an area roughly equivalent to their daily movement range (see Section 2.7.2).

2.4.3. Interaction. Two forms of direct interaction between individuals are included in the model. Mating can occur any time and is determined by males finding nearest females that are in estrus. Hog movement is partially determined by interaction tolerances in which younger hogs are less likely to go to a cell with older hogs. These tolerances are differentiated by sex and described in detail in the movement submodel.

2.4.4. Stochasticity. Almost all parameter values and events occur based on uniform or normal distributions. Timers like gestation and estrus clocks do not vary.

2.4.5. Observations. Spatial and temporal size and structure of the population are compared.

2.5. Initialization. The model starts on June 1, 1980. Individual hogs were randomly placed in cells within GSMNP and in southern areas of the surrounding region. We estimated initial densities and spatial distributions on empirical data from the early 1980s (Singer et al. [1981], SCWDS [1988]). Initial age structure followed existing demographic data (Mayer [2009]). Food is placed on the landscape based on forest type and month as described in Section 2.7.1. Because of the randomness of the initialization of the model, data are not collected from the model until 1990 to allow for sufficient mixing.

2.6. Input data. The amount of calories (i.e., food) available to hogs is input each month from a table that is delineated by forest type. The fall mast index value is also input from a table.

\subsection{Submodels.}

2.7.1. Mast layer. In the southern Appalachians, tubers, herbaceous material, and hard mast are hogs' principal food sources for most of the year (Howe et al. [1996]). Tubers (squawroot and spring beauties) and herbaceous material provide most of the nutrition during summer. Hard mast, which includes acorns and other dry fruits, provides vital nutrition during the fall (Henry and Conley [1972]). Hogs use hard mast to gain fat reserves for the winter period, which is important for 


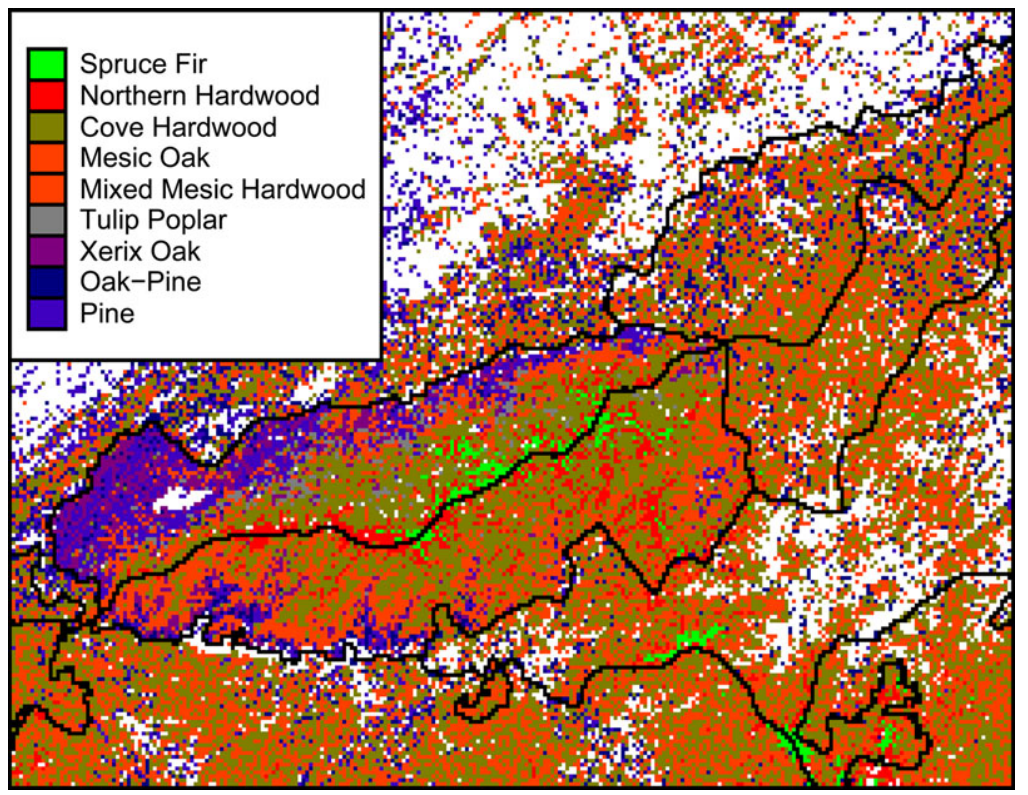

FIGURE 3. Forest raster map for the study region based on the classification done by Mackenzie [1993]. The Northern Hardwood to Mixed Mesic Hardwood classes comprise the preferred feral hog habitat in the park.

reproductive success. Fall hard mast failures occur, on average, every four to 5 years (Koenig and Knops [2000]).

Food availability was simulated using a forest map layer that included nine forest types and one nonforest type (Figure 3) (Mackenzie [1993]). Kilocalories (kcal) of available food throughout the year were estimated for each forest class using data derived for the northwestern section of GSMNP in 1995 (Inman and Pelton [2002]). The available kilocalories were updated every 2 weeks throughout the year. Kilocalories for each vegetation type for each month was estimated during 1995 (Inman and Pelton [2002]). Because 1995 was an average fall mast year, the data were scaled up to approximate maximum mast availability (Figure 4). Mast availability per cell was estimated as follows:

$$
\begin{aligned}
\operatorname{Calories}(i, j)[t]= & \text { Calories }(i, j)[t-1] \\
& + \text { Cal }_{\text {Max }} * \text { Cal }_{H} * \text { Mast_level }
\end{aligned}
$$

where:

- $i, j$ designate the coordinates of the cell. 


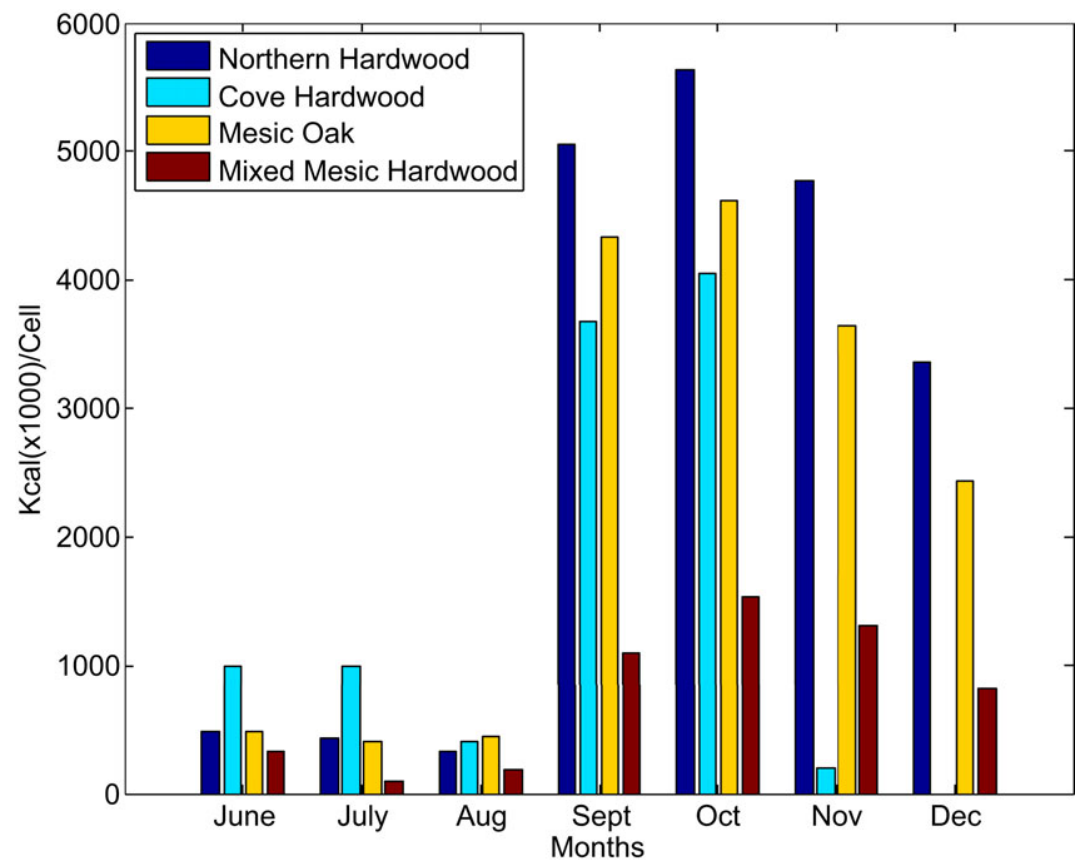

FIGURE 4. Maximum amount of kilocalories available in each cell per month of the four vegetation types that have the highest impact on fall hard mast.

- Cal $_{\text {Max }}=$ Calories $_{v e g \_t y p e}\left[\right.$ month $\left._{t}\right] / 2$, represents the number of kilocalories of the forest type in cell( $\mathrm{i}, \mathrm{j})$ for the month of time $t$. It is divided by 2 because mast is replaced every 14 days in the model.

- $\mathrm{Cal}_{H}$ is the proportion of the kilocalories available to hogs. Between $70 \%$ to $90 \%$ of mast is used by birds and small mammals (Vaughan [2000], Inman and Pelton [2002]). For the summer, we assume $30 \%$ is available, whereas only $10 \%$ is assumed to be available during the fall.

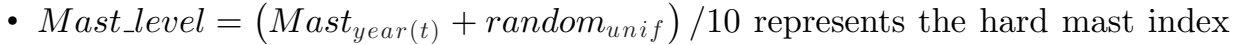

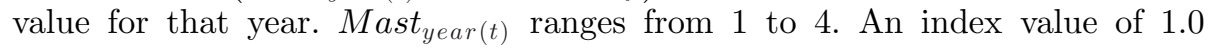
represents a failure and 4.0 represents maximum hard mast production. Because no data were available on soft mast variation during summer, we assumed Mast $_{\text {year }(t)}=3$ for every year. In a given year, not all trees produce the same amount of mast (Greenburg [2000]). Therefore, to allow for spatial variability, the actual index value in each cell is uniformly distributed between $[$ Index -0.5, Index +0.5$]$. The number was then divided by 10 to represent the value as a proportion. During the time period of our model, mast failures occurred in 1992, 1997, 2000, 2003, and 2009. 
Equation (1) does not represent the actual number of kilocalories in each cell. Instead, it is a metric of available food.

2.7.2. Movement. Movement was modeled solely based on food availability and a hierarchical dominance structure in which older individuals had priority in choosing cells. The model assumed hogs move to cells with the most food. There are two components to hog movement: dominance and daily range.

Dominance was defined by age and differentiated by sex. A male could move into a cell if there were no older males within a one-cell radius, whereas females (and their piglets) could enter a cell if there were no older females in that cell (0-cell radius). This structure results in females have subadult daughters closer in proximity than sons. The difference in this "tolerance" spacing between males (1-cell radius) and females (0-cell radius) is supported by data suggesting that females are more tolerant than males and often share home ranges with female offspring (sounders) (Gabor et al. [1999]).

Each hog searched outwardly from its current cell. Males could move as far as four cells in one day $(2 \mathrm{~km})$, whereas females were limited to two $(1 \mathrm{~km})$ (Singer et al. [1981]) . If a hog was unable to find a suitable cell, it was randomly placed in one of the cells in its outer daily movement range. Because the cells are $450 \mathrm{~m} \times 450 \mathrm{~m}$ and empirical densities form the early 1980s suggested up to nine individuals per $\mathrm{km}^{2}$, more than one hog can occupy the same cell (Singer et al. [1981]). The movement rules allow for this because older hogs can move to any cell despite the number of younger hogs in it. Order of movement is determined by randomly selecting hogs.

If a female is in estrus, the nearest adult male (in a 10 cell radius) is moved to her cell to copulate. Once copulation occurs, both male and female move to find food according to the above rules.

2.7.3. Update food. Feral hog food preferences throughout the year has been well studied (Scott and Pelton [1975], Ackerman et al. [1978], Singer et al. [1981]), but the seasonal variation of the amount of food consumed is not as well documented. A slightly modified version of Nelson's (1980)(Nelson et al. [1980]) monthly caloric intake estimates for black bears is used in the model. These values included (in kcal/day): 1000 (January, February, and March), 1500 (April), 2000 (May), 3000 (June and July), 4000 (August), 6000 (September), 7000 (October and December), and 10,000 (November). These are meant to represent the increased caloric value of fall mast and the increase in foraging during the fall (Inman and Pelton [2002]).

2.7.4. Update food reserve. We do not attempt to model hog weight. Rather, the model keeps track of the net kilocalories stored.

$$
\operatorname{Cal}_{\text {total }}(t)=\operatorname{Cal}_{\text {total }}(t-1)+0.4 * \text { intake }(t)-\text { cost }_{\text {move }} .
$$


The value 0.4 corresponds to the proportion of the consumed kilocalories that are converted to stored fat, also in kilocalories. It should be emphasized that this was an approximation to capture the general dynamics, not a specific estimate of actual kilocalories. Because of a lack of data on the actual metabolic cost of movement, we assumed cost $_{\text {move }}=1000 \mathrm{kcal}$.

2.7.5. Mortality. The model addresses two types of adult mortality: natural and harvest. Natural mortality included deaths due to disease and other noninteractive types. This mortality (0.0011/day) is applied to every hog (not piglets) daily and corresponds to a $33 \%$ annual mortality rate. Public hunting is not permitted within GSMNP, but harvest for control purposes is conducted. The GSMNP harvest occurs throughout the year with a daily harvest rate of 0.0005 . There were no empirical harvest data that could be used to determine the harvest effort outside GSMNP. There is a significant harvest, but because our focus was GSMNP, we assume the harvest rate is $50 \%$ of the natural mortality rate $(0.00055 /$ day $)$. This, near $50 \%$ overall mortality rate (natural and harvest) is similar to empirical data (Mayer [2009]). We assumed that mortality of a mother would result in mortality of her litter.

Piglet-specific mortality was modeled during the weaning stage. If a female's caloric reserves fell below the threshold value at any point during weaning, the litter died. This was modeled by decreasing the stored calories based on the following equation:

$$
\operatorname{Cal}(t)=\operatorname{Cal}(t-1)-400 * \text { num }_{\text {piglets }} .
$$

If $\mathrm{Cal}(t)<20,000 \mathrm{kcal}$, then all piglets were lost. This threshold was estimated from empirical piglet morality estimates during good and bad mast years (see Section 3 ).

2.7.6. Update state variables. The update state variables function updated all the relevant state variables at the end of each day. These variables included age, days in estrus, and days weaning piglets. All the checks for timed variables occurred at this point.

2.7.7. Reproduction. Reproduction in feral hogs is characterized by three distinct phases: mating, gestation, and weaning. Mating can occur during any time of the year, but peaks occur in late spring and fall. This results in farrowing female peaks in late summer and winter (Figure 5) which matches empirical data (Johnson et al. [1982]). It is important to note that these patterns are an emergent property of the food resources available and the reproductive parameters. Primiparity in females occurs at 1 year. Reproductively viable females were assigned estrus if they were not pregnant or weaning. Females were in estrus for 21 days or until 


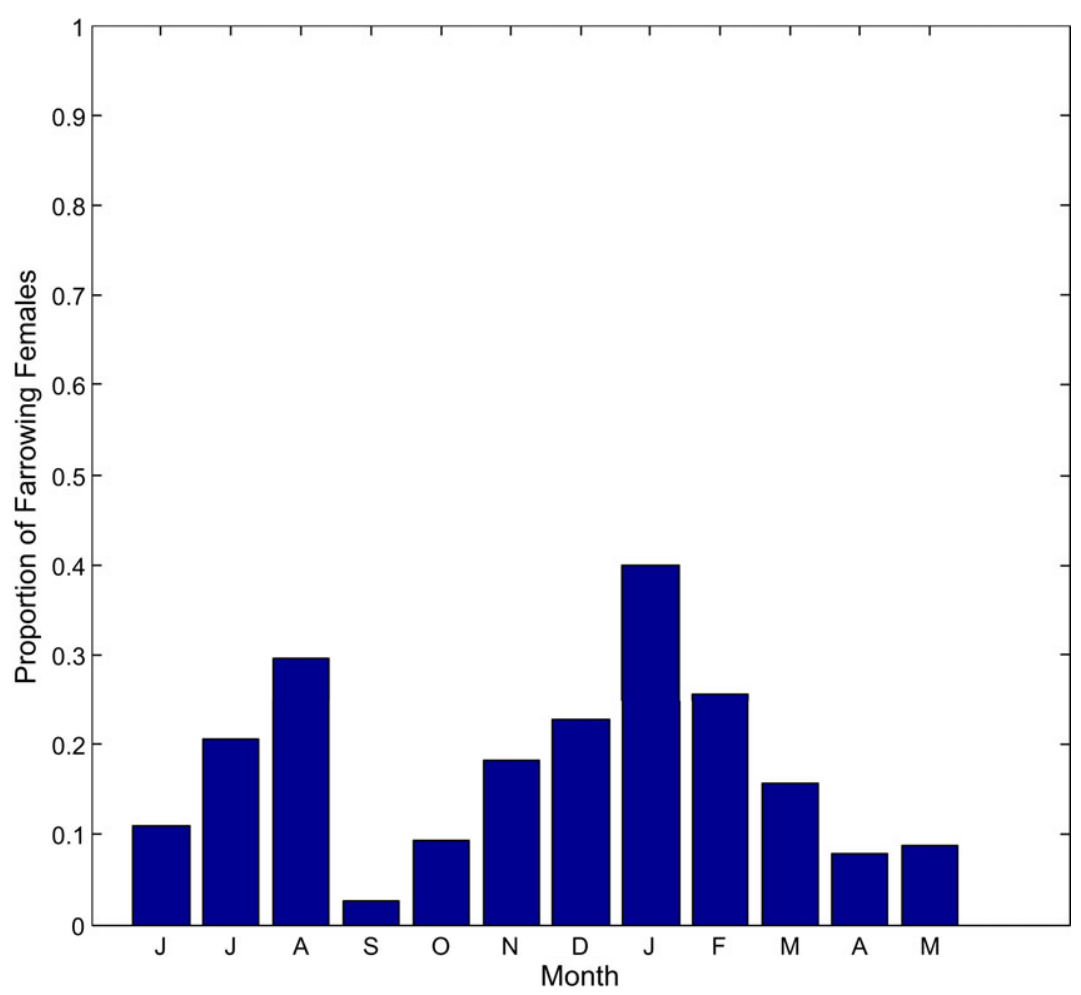

FIGURE 5. Average proportion of females farrowing (have a litter) for each month for 1990-2010.

copulation occurred (Henry [1968]). Once copulation had occurred, a gestation timer was started for the pregnancy. A 115-day gestation was assumed (Henry [1968]). Litter sizes varied from three to seven piglets (equal sex ratio) with the following probabilities (estimated from Singer et al. [1981]): $p(3)=0.1, p(4)=0.35$, $p(5)=0.3, p(6)=0.15, p(7)=0.1$. Mothers nursed their piglets for 3 months after which the piglets left their mother and entered the population. All females that lost piglets entered estrus after 2 weeks.

2.8. Implementation. The model was coded in $\mathrm{C}++$ and compiled on a UNIX platform using $\mathrm{g}++$. A model run involved 20 independent iterations, each with different random number generator seeds. The resulting averages and $95 \%$ confidence intervals were used to present the data (except for the spatial maps in which a single simulation was used to create the images). 


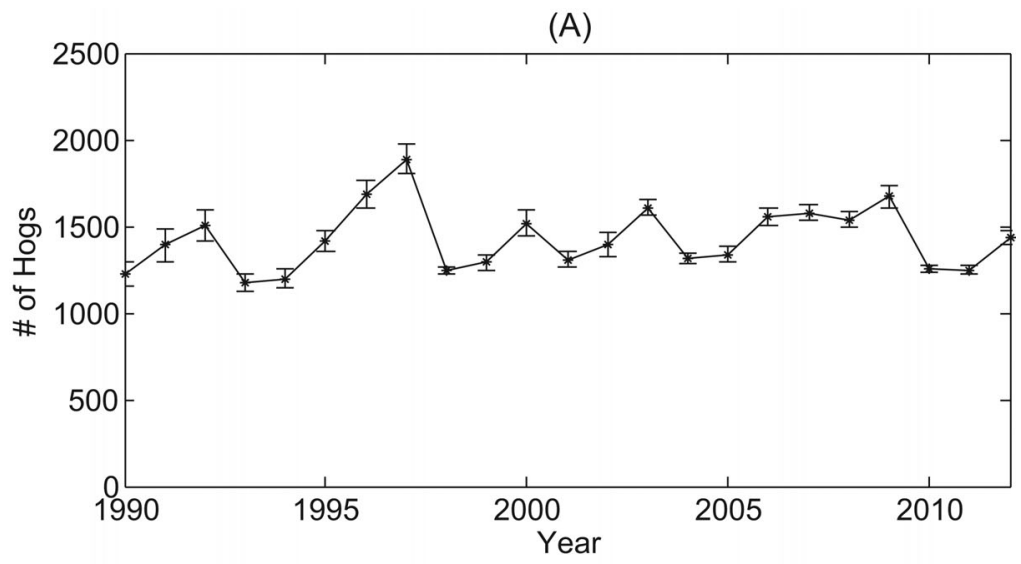

(B)

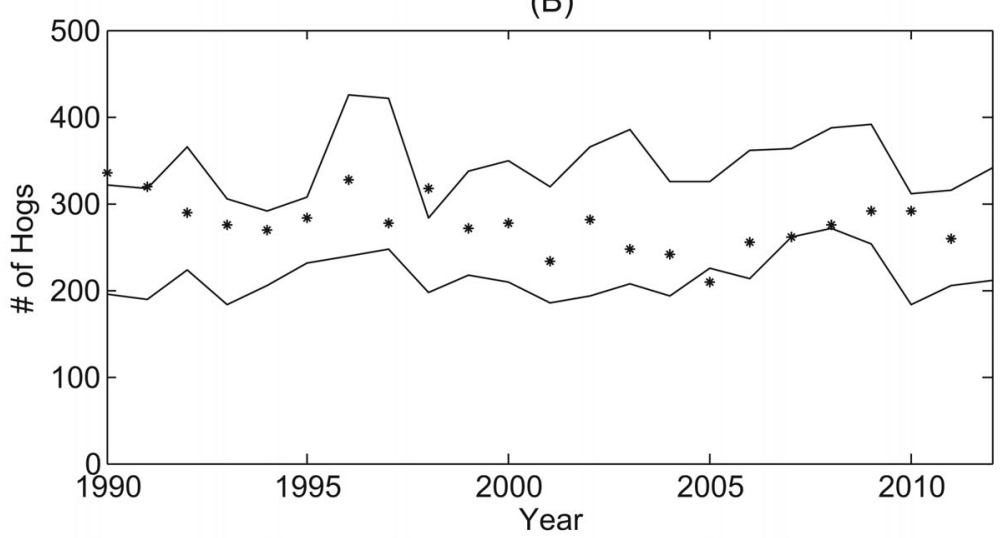

FIGURE 6. Model comparisons with GSMNP empirical harvest data: (A) GSMNP population size (95\% CI) and (B) 95\% CI for IBM harvest data (solid lines) and 3 year running average of GSMNP harvest data.

\section{Results.}

3.1. Model evaluation. Figure 6(A) shows IBM output for the GSMNP population. Note the decreases in population associated with the fall mast failures of 1992, 1997, 2000, 2003, and 2009. Figure 6(B) compares GSMNP harvest numbers. The IBM outputs (solid lines) indicate the upper and lower 95\% CIs. The asterisks indicate the 3-year running average for the empirical harvest data. We chose the running average to minimize the year-to-year variation in effort that the model does not address. Because the model assumes a constant harvest rate, any variation will be a function of population size. 

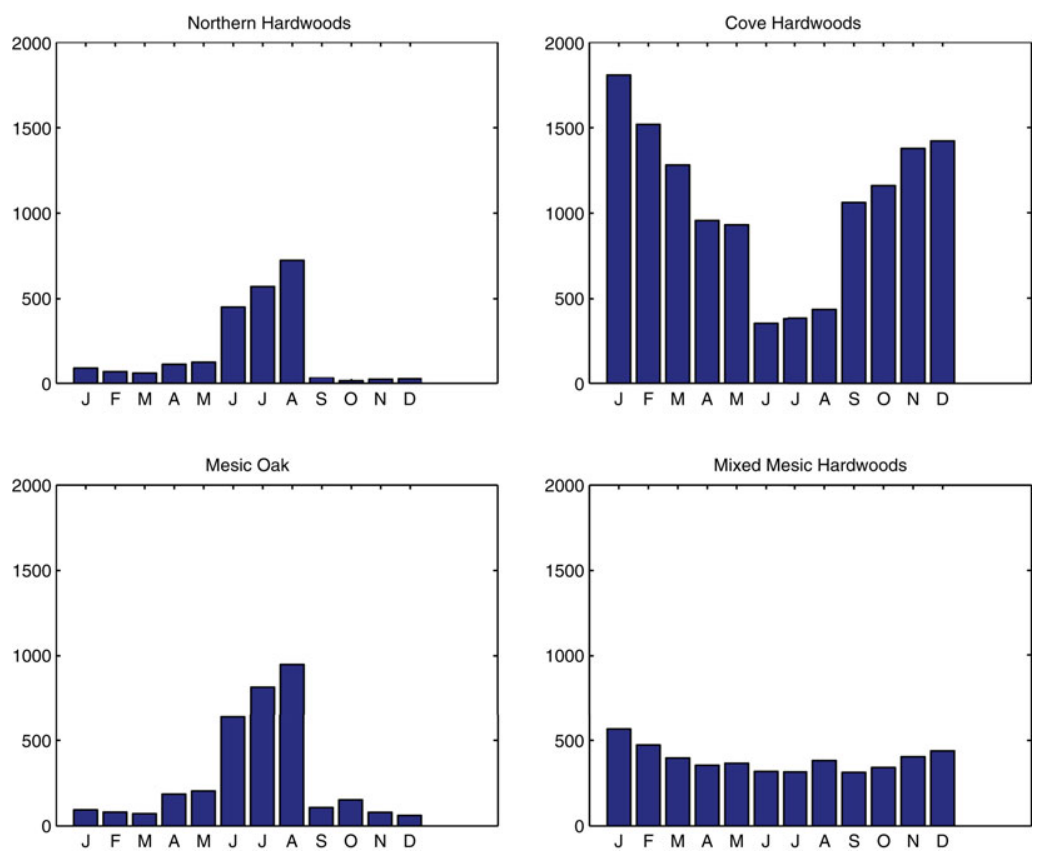

FIGURE 7. Monthly population size of feral hogs in the four dominant (in terms of hog population size) forest types: (A) Northern Hardwood, (B) Cove Hardwoods, (C) Mesic Oak, and (D) Mixed Mesic Hardwoods.

To determine whether the hogs were moving seasonally, their location was recorded each month with respect to forest type. The dominant types were Northern Hardwood, Cove Hardwood, Mesic Oak, and Mixed Mesic Hardwoods. Figure 7 shows the number of individuals in each forest type throughout the year. These data are averaged for each month form 1990 to 2009. The results follow the empirical observation that hogs move to the higher elevation (Northern Hardwoods and Mesic Oak) during the summer (Singer et al. [1981]).

To determine if the population is dispersing at a reasonable rate, model output of feral hog locations can be compared to the corresponding feral swine distribution maps (SCWDS [1988], SCWDS [2013]). Figure 8 shows the spatial distribution of hogs from a 1-day snapshot in 1988 and 2013. The empirical boundaries correspond to the spatial boundaries from these maps.

Feral hogs can reproduce year-round, with some females having multiple litters/year. We define a successful litter if a female and her piglets survive to 65 weaning days (about two-thirds of weaning time). Given that metric, an average of $28 \%(0.02,95 \% \mathrm{CI})$ of the females had $1 \mathrm{~L}$ and $5.5 \%(0.009)$ had two. Empirical data showed $5 \%$ of females had second litters in GSMNP (Singer et al. [1981]). 
(A)

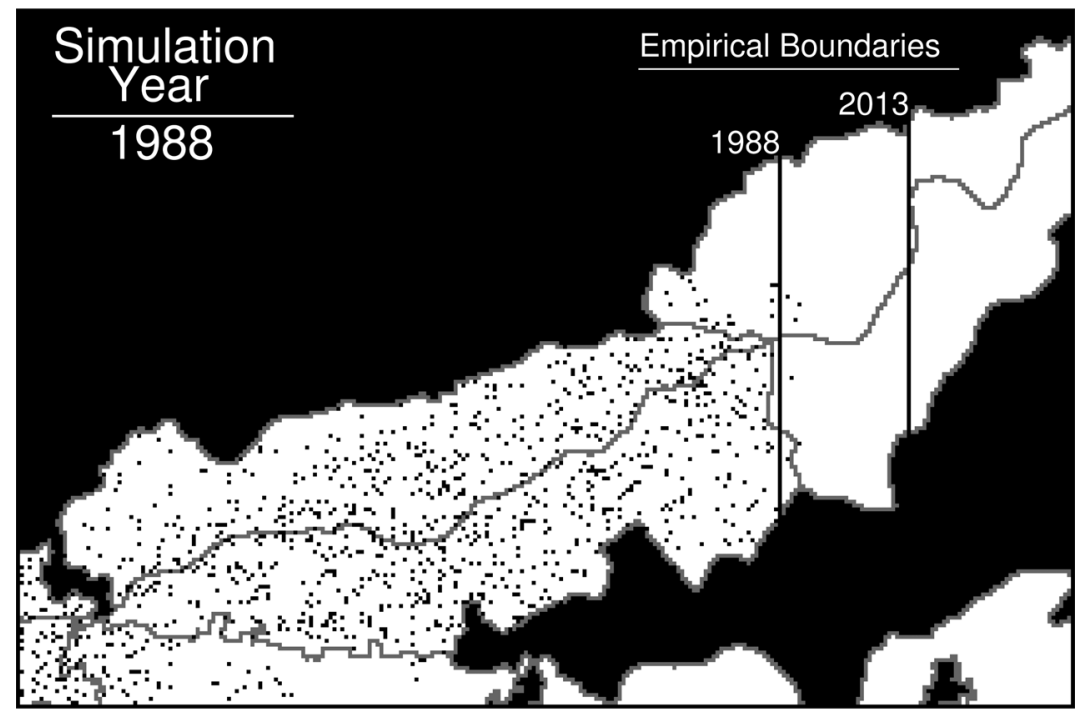

(B)

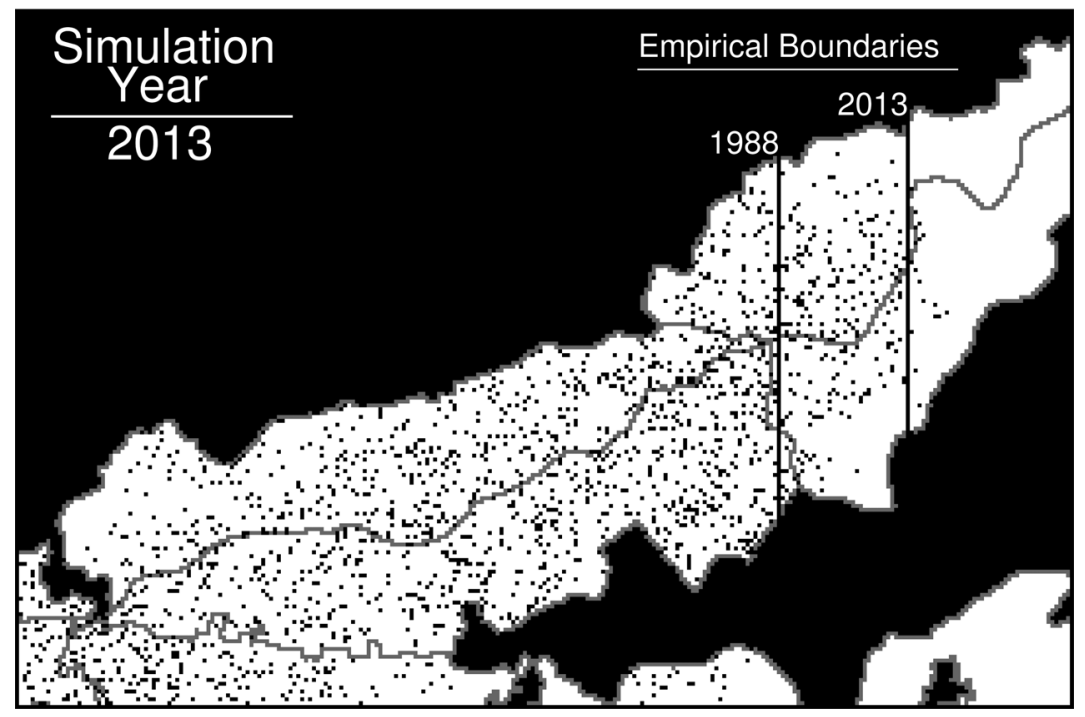

FIGURE 8. The distribution of feral hogs on the landscape from a 1-day snapshot for the base mortality in (A) 1988 and (B) 2013. A marked cell (black dots) indicates at least one hog in that cell. The empirical vertical line boundaries correspond to the western range of the feral hog population in the SCWDS data set. 
(A)

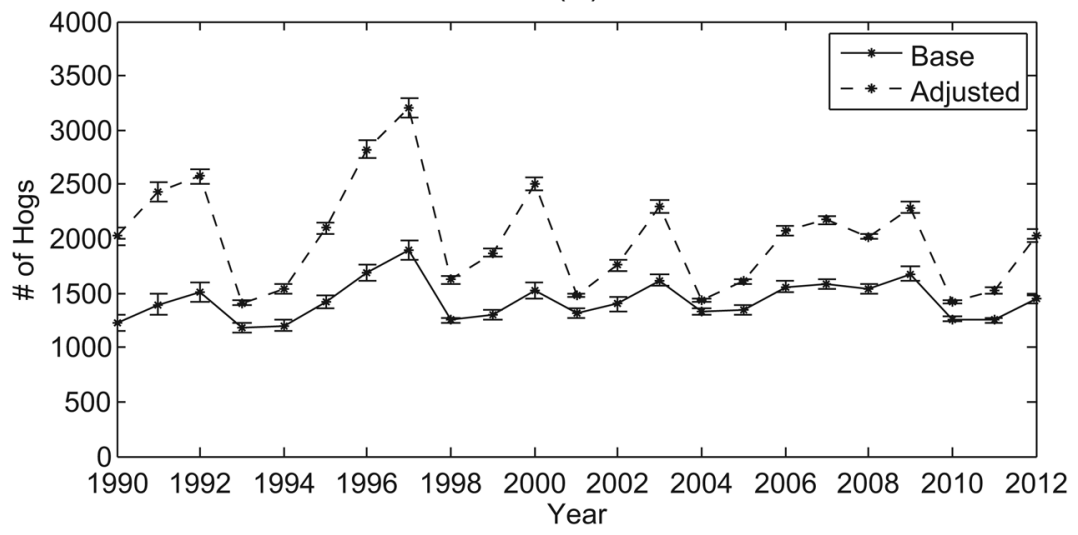

(B)

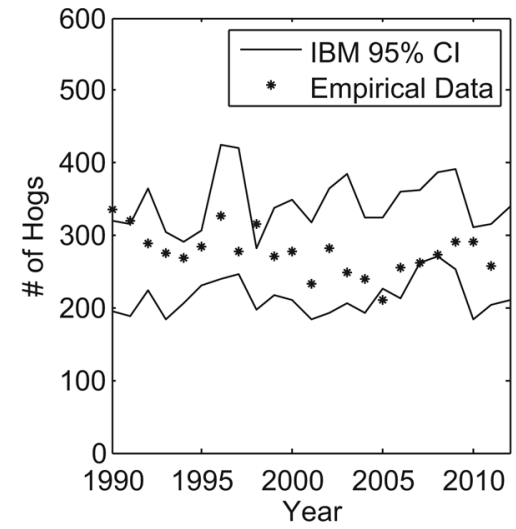

(C)

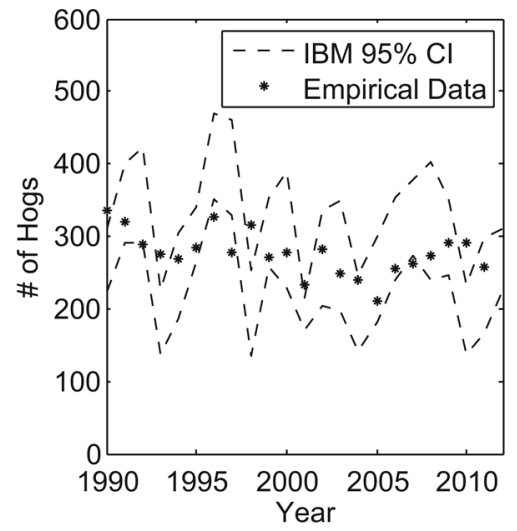

FIGURE 9. Comparison of the base and adjusted (20\% decrease) mortality rates to estimate the parameter values. (A) GSMNP population (95\% CIs), (B) base mortality rates $(95 \%$ CI boundaries) and empirical harvest numbers, and (C) adjusted mortality rates (95\% CI boundaries) and empirical harvest numbers.

The natural and harvest mortality rates were estimated by comparing combinations of rates to the empirical harvest data and the spatial distribution. Both comparisons were needed since it is possible for multiple combinations of mortality rates to have reasonable harvest numbers. Figure 9 compares the natural mortality rate used in the model (base) to a $20 \%$ decrease (Adjusted). Because decreasing the natural mortality rate would increase the number of harvested hogs, the harvest rate was also decreased by $20 \%$. Both model runs are reasonable estimates of the harvest numbers, but give two significantly different average harvest rates $(0.2$ and 0.14 , respectively). It becomes clear when comparing the adjusted mortality data to 
the feral hog distribution data (SCWDS [2013]) that the decreased mortality rates resulted in a significant increase in the spread of feral hogs (Figure 10). An increase in the natural mortality rate resulted in a smaller population in which harvesting rates could not produce enough harvested hogs.

3.2. Management impact. Currently, harvesting is the only form of control for feral hogs. Although the model could be used to consider variation in space, time, and effort in harvesting, we focus this analysis on assessing the impacts of the current harvesting effort. Limited resources and other constraints (e.g, tourists and terrain) restrict the control strategies available.

To determine the effect of the harvesting effort in GSMNP on the population size, a set of runs in which the harvest is ended in 1990, were compared to the current strategy (Figure 11). Percent growth was defined as the relative difference between the 2013 and 2019 population sizes. Model results suggest that without harvesting the percent growth between 2013 and 2019 would result in a $24 \%$ increase in the population. Figure 12 illustrates the impact of various potential annual harvest rates on the percent growth from 2013 to 2019. We used a resampling of the previous mast index values to project future mast availability.

4. Discussion. We developed an IBM for feral hogs in GSMNP to provide managers with insights into the impact of their annual harvest on the population. Our results suggest that the GSMNP has a 19.6\% annual harvest rate and that eliminating the harvest would result in a $24 \%$ relative increase in the population from 2013 to 2019. Projections indicate that an annual harvest rate of over $40 \%$ would be required to decrease the percent growth in that time frame. These results are similar to some published data (Klinger et al. [2011]), but smaller than others (Dzieciolowski et al. [1992], Hess et al. [2006]). In all cases, it takes a significant harvest rate to control the population. The GSMNP population may require a smaller harvesting effort due to the impact of fall hard mast variation in the population.

To model the impact of fall hard mast variation, we varied the amount of food available to hogs based on forest type and historical mast index values. Our output showed that mast variation affected hog movement and reproductive success. Given those dynamics, we concluded that fall hard mast is a natural population regulator. The annual variation in hard mast creates a fluctuating carrying capacity, which in years of low mast production, drives hogs out of the park and limits reproductive success. This corroborates similar findings (Massei et al. [1981], Johnson et al. [1982]).

When considering the accuracy of the model results, it is important to understand that this model is not meant to estimate the number of hogs in GSMNP. It does however provide a reasonable estimate of population size and the model holds up to the limited empirical data available. The real value of the model is that can 
(A)

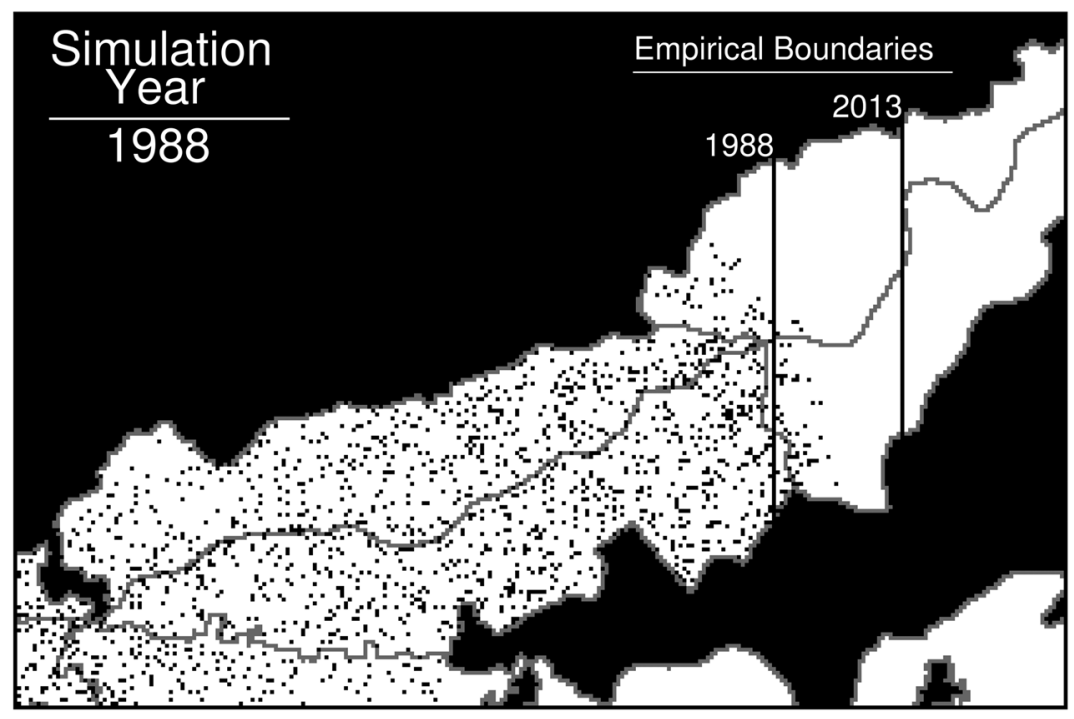

(B)

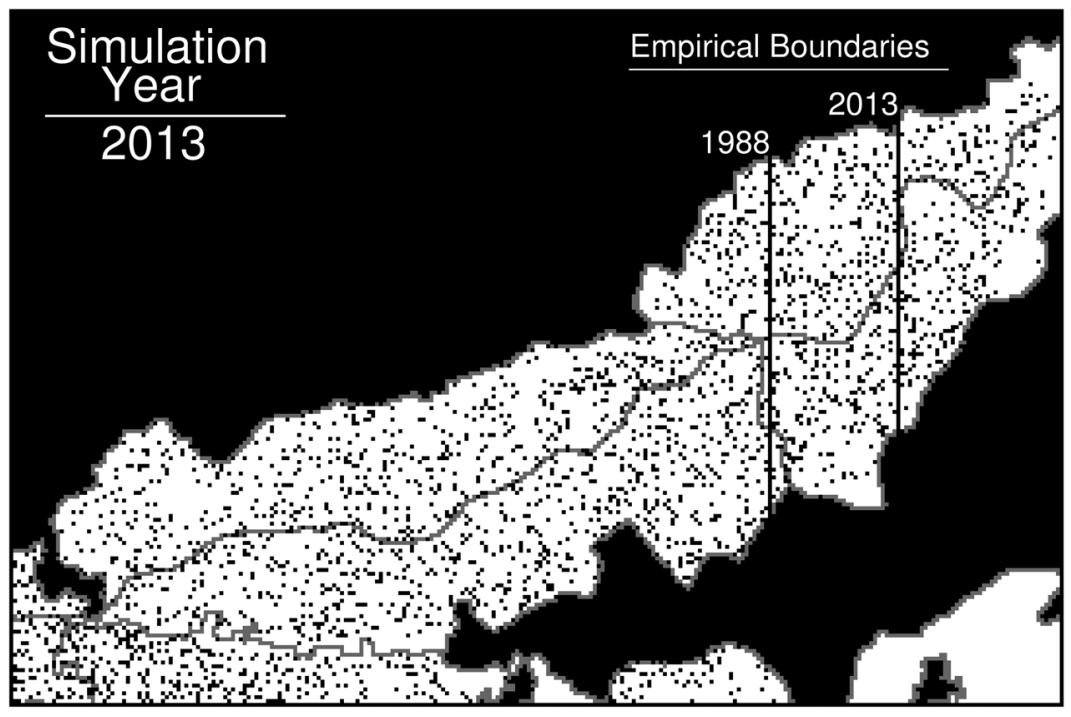

FIGURE 10. The distribution of feral hogs on the landscape from a 1-day snapshot for the adjusted mortality in (A) 1988 and (B) 2013. A marked cell (black dots) indicates at least one hog in that cell. The empirical vertical line boundaries correspond to the western range of the feral hog population in the SCWDS data set. 
(A)

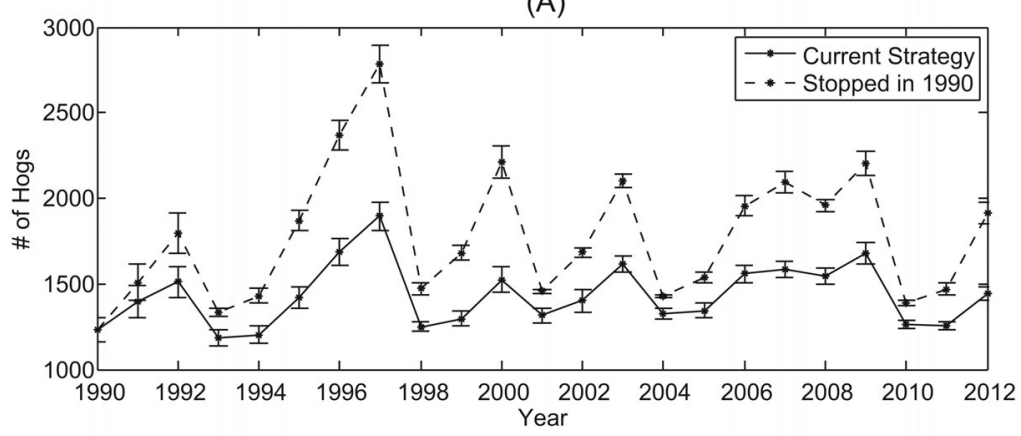

(B)

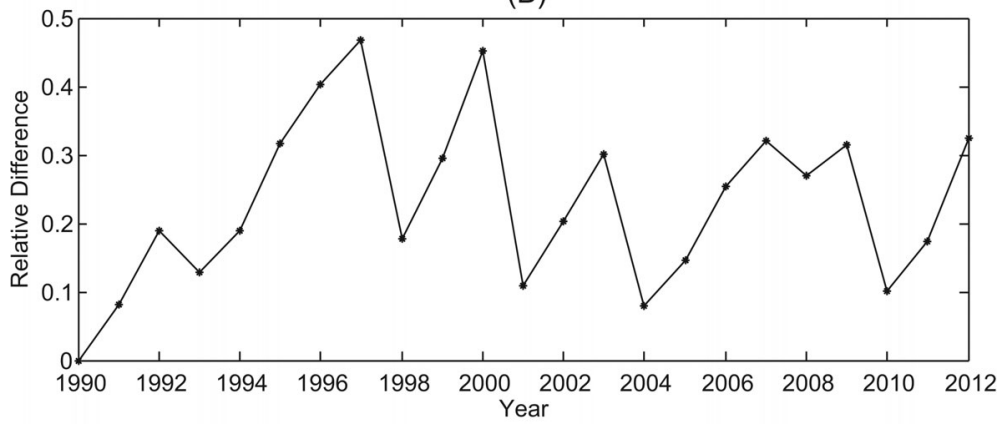

FIGURE 11. (A) The impact of not hunting since 1990 (dashed) and the current strategy (solid). Error bars indicate 95\% CIs. (B) The relative difference of not hunting.

provide additional insights into the population dynamics of feral hogs. The model shows the interplay between mast variation and movement and survival rates, and describes the change in spatial distribution of the population.

Acknowledgments. This work is part of a Working Group at the National Institute for Mathematical and Biological Synthesis, an Institute sponsored by the National Science Foundation, the U.S. Department of Homeland Security, and the U.S. Department of Agriculture through NSF Award EF-0832858, with additional support from The University of Tennessee, Knoxville.

\section{REFERENCES}

B.B. Ackerman, M.E. Harmon, and F.J. Singer [1978], Part II. Seasonal Food Habits of European Wild Boar - 1977 Great Smoky Mountains National Park, in (F. J. Singer, ed.), Studies of European Wild Boar in the Great Smoky Mountains National Park. Upland Field Research Laboratory, Great Smoky Mountains National Park, 137 pp.

R.M. Dzieciolowski, C.M. Clarke, and C.M. Frampton [1992], Reproductive Characteristics of Feral Pigs in New Zealand, Acta Theriol. 37(3), 259-270. 


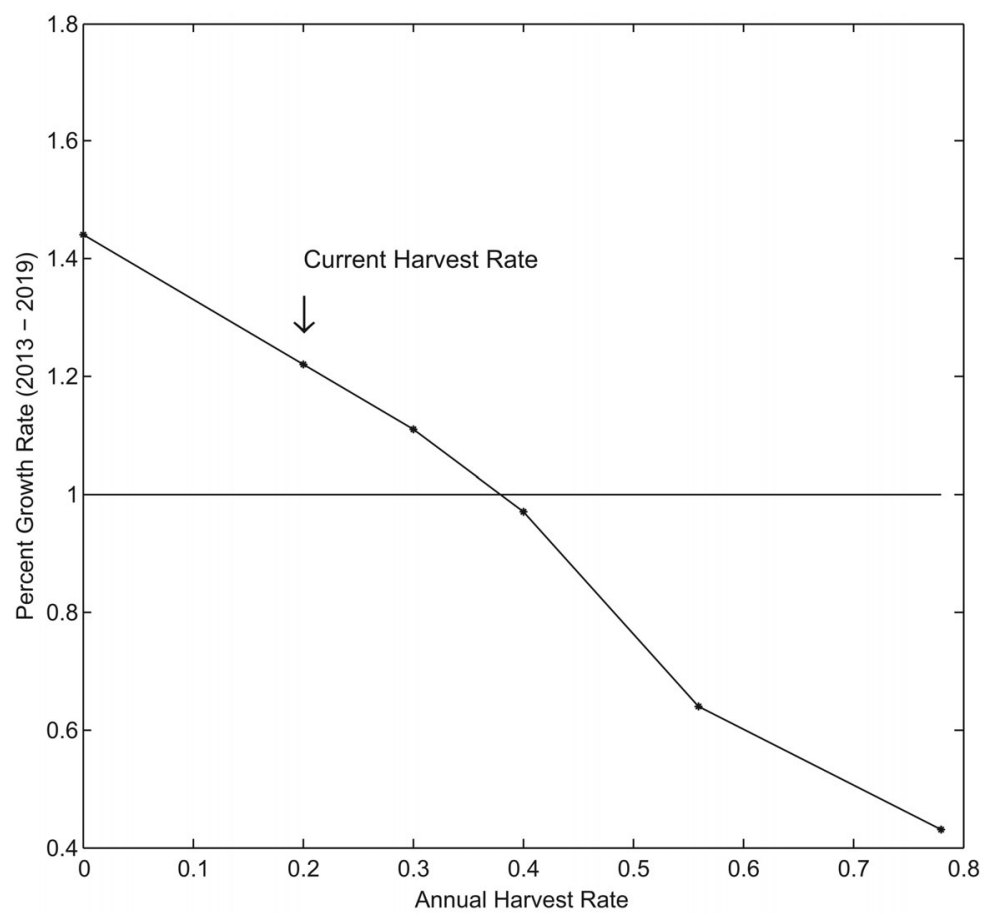

FIGURE 12. Percent growth rate as a function of annual harvest rate for a 6 -year projection (2013-2019).

T.M. Gabor, E.C. Hellgren, R.A.V.D. Bussche, and N.J. Silvy [1999], Demography, Sociospatial Behavior and Genetics of Feral Pigs (Sus scrofa) in a Semi-arid Environment, J. Zool., Lond. 247, 311-322.

C. Greenburg [2000], Individual Variation in Acorn Production by Five Species of Southern Appalachian Oaks. Forest Ecol. Manage. 132, 199-210.

V. Grimm, U. Berger, F. Bastiansen, S. Eliassen, V. Ginot, J. Giske, J. Goss-Custard, T. Grand, S. Heinz, G. Huse, A. Huth, J. Jepsen, C. Jørgensen, W. Mooij, B. Mÿller, G. Pe’er, C. Piou, S. Railsback, A. Robbins, M. Robbins, E. Rossmanith, N. Rÿger, E. Strand, S. Souissi, R. Stillman, R. Vabi, U. Visser, and D. DeAngelis [2006], A Standard Protocol for Describing Individual-Based and Agent Based Models. Ecol. Model. 198, 115-126.

V. Grimm, U. Berger, D.L. DeAngelis, J.G. Polhill, J. Giske, and S.F. Railsback [2010], The ODD Protocol: A Review and First Update. Ecol. Model. 221, 2760-2768.

V.G. Henry [1968], Length of Estrous Cycle and Gestation in European Wild Hogs. J. Wildlife Manag. 32, 406-408.

V.G. Henry and R.H. Conley [1972], Fall Foods of European Wild Hogs in the Southern Appalachians, J. Wildlife Manage. 36, 854-860.

S.C. Hess, J.J. Jeffrey, D.L. Ball, and L. Babich [2006], Efficacy of Feral Pig Removals at Hakalau Forest National Wildlife Refuge, Trans. Western Sec. Wild. Soc. 42, 53-67.

T.D. Howe, F.J. Singer, and B.B. Ackerman [1996], Forage Relationships of European Wild Boar Invading Northern Hardwood Forest, Acta Theriol. 41(3), 307-320. 
R.M. Inman and M.R. Pelton [2002], Energetic Production by Soft and Hard Mast Foods of American Black Bears in the Smoky Mountains, Ursus 13, 57-68.

K.G. Johnson, R.W. Duncan, and M.R. Pelton [1982], Reproductive Biology of European Wild Hog in the Great Smoky Mountains Natonal Park, Proc. Ann. Conf. Southeastern Assoc. Fish and Wild. Agencies 36, 552-564.

R. Klinger, J. Conti, J.K. Gibson, S.M. Ostoja, and E. Aumack [2011], What Does It Take to Eradicate a Feral Pig Population?, in (C. R. Veitch, M. N. Clout, and D. R. Towns, eds.), Island Invasions, Eradication and Management, IUCN, pp. 78-86.

W. Koenig and J. Knops [2000], The Behavioral Ecology of Masting in Oaks, in (W. McShea and W. Healy, eds.), Oak Forest Ecosystems, Johns Hopkins University, pp. 129-148.

S. Lowe, M. Browne, S. Boudjelas, and M.D. Poorter [2000], In 100 of the World's Worst Invasive Aalien Species: A Selection from the Global Invasive Species Database. ISSG.

M.D. Mackenzie [1993], The Vegetation of Great Smoky Mountains National Park: Past, Present, and Future, Ph.D. thesis, University of Tennessee, Knoxville.

G. Massei, P.V. Genov, and B.W. Staines [1981], Diet, Fod Availability and Reproduction of Wild Boar in a Mediterranean Coastal Area, J. Wildlife Manage. 45, 748-754.

J.J. Mayer [2009], Estimation of the Number of Wild Pigs in the United States. SRNL-STI2014-00292. Savannah River National Laboratory, 8 pp.

A.J. McClane, C. Semeniuk, G.L. McDermid, and D.J. Marceau [2011], The Role of Agent-Based Models in Wildlife Ecology and Management, Ecol. Model. 222, 1544-1556.

R. Nelson, G.F. Pfeiffer, E. Craighead, J. Jonkel, and D. Steiger [1980], Behavior, Biochemistry, and Hibernation in Black, Grizzly, and Polar Bears, Int. Conf. Bear Manage. 5, 284-290.

C.D. Scott and M.R. Pelton [1975], Seasonal Food Habits of the European Wild Hog in the Great Smoky Mountains Natonal Park. Proc. Ann. Conf. Southeastern Assoc. Fish Wild. Agencies 29, 585-593.

SCWDS [1988], Southern Cooperative Wildlife Disease Study. Feral/Wild Swine Population, College of Veterinary Medicine, University of Georgia, Athens.

SCWDS [2013], Southern Cooperative Wildlife Disease Study. Feral/Wild Swine Population, College of Veterinary Medicine, University of Georgia, Athens.

F.J. Singer [1981], Wild Pig Populations in the National Parks. Environ. Manage. 5, 263-270.

F.J. Singer, D.K. Otto, A.R. Tipton, and C.P. Hable [1981], Home Ranges, Movements, and Habitat Use of European Wild Boar in Tennessee, J. Wildlife Manage. 45, 343-353.

W.H. Stiver and E.K. Delozier [2009], Great Smoky Mountains National Park, in (J. J. Mayer, and I. L. Brisbin, eds.), Wild Pigs: Biology, Damage, Control Techniques, and Management, 400 pp. SRNL-RP-2009-00869.

M.R. Vaughan [2000], Oak Trees, Acorns, and Bears, in (W.J. McShea and W.M. Healy, eds.), Oak Forest Ecosystems, Johns Hopkins University, pp. 224-240.

Mayer, J. J. 2009. Wild pig population biology. Pp. 157-191. In J. J. Mayer and I. L. Brisbin, Jr. (eds.). Wild Pigs: Biology, Damage, Control Techniques and Management. SRNL-RP-2009-00869. Savannah River National Laboratory, Aiken, South Carolina, USA. 400 pp. 